\title{
TOXICITY AND BIOACCUMULATION OF CADMIUM IN THE FRESHWATER BIVALVE CORBICULA FLUMINALIS MÜLLER, 1774.
}

\author{
Soad S. Abdel Gawad \\ National Institute of Oceanography and Fisheries, Inland Water and \\ Aquaculture Branch. \\ 101 Kasr Al Eini St., Cairo, Egypt \\ E.mail: s_abdou_eg@yahoo.com
}

Keywords: Corbicula fluminalis, cadmium, bioaccumulation, survival, soft tissue, shell.

\begin{abstract}
The influence of different concentrations of cadmium on Corbicula 1 fluminalis was examined by a toxicity experiment. Acute toxicity was analyzed by measurement of the 96h. LC50 and daily survival rates. Results indicated that the mortality rate of Corbicula fluminalis was proportional to the concentration of cadmium. LC50 after $96 \mathrm{~h}$. exposure was $0.52 \mathrm{mg} / \mathrm{l}$. The bioaccumulation value of the pollutant in the clam's soft parts were higher than the corresponding values in the shell after 96 h. exposure. The bioaccumulation of cadmium in the organism increased by increasing the concentration of cadmium in solution from $119 \mathrm{mg} / \mathrm{kg}$ in $0.02 \mathrm{mg} / \mathrm{l}$ to $168 \mathrm{mg} / \mathrm{kg}$ in soft tissue in $8 \mathrm{mg} / \mathrm{l}$. The increase of cadmium in the organism was not steady, but it took the form of sudden increase after increasing the concentration of cadmium in solution to 8 $\mathrm{mg} / \mathrm{l}$.
\end{abstract}

\section{INTRODUCTION}

The exotic bivalve, Corbicula was introduced into U.S.A. in the 1930s, (Isom, 1986; McMahon, 1991). It has successfully invaded many lakes and streams and often occurs in dense aggregations. One reason for its success may be that it can feed both from the water column (using siphons to filterfeed) and from the sediments (using the foot to pedal feed) (Reid et al., 1992; Hakenkamp \& Palmer, 1999).

Corbicula is known to feed on bacteria and phytoplankton in the water column via filter feeding (Phelps, 1994; Silverman et al., 1995; Boltovskoy et al., 1995), but its effect on the benthos is unknown. 
Vaughn \& Hakenkamp (2001) stated that these bivalves can directly affect benthic processes as they burrow throught sediments.

Cadmium is a metalic contaminant that has no known essential functions of human physiology (Barak \& Mason, 1990). It has gained wide interest in the scientific community in recent years due to its potential human health hazards (Selvi et al., 2003). The main source of cadmium pollution is through soil. Cadmium released from factory wastes and mining operations also pollutes water and feed crops (Ibrahim et al., 1997). Some authors studied the effect of cadmium on some freshwater bivalves including Ibrahim et al. (1997) on Caelatura aegyptiaca, Saad and Emam (1998) on Caelatura teretiuscula \& Abdel Gawad (2005) on Caelatura prasidense.

No published data on the effect of cadmium on Corbicula fluminalis are yet available in Egypt. Therefore the present work aimed to assess the toxicity of $\mathrm{Cd}$, as one of the most toxic metals frequently encountered in polluted areas, on Corbicula fluminalis and the ability of this freshwater bivalve to accumulate this toxic metal.

\section{MATERIAL AND METHODS}

Adult specimens of the bivalve Corbicula fluminalis were collected from the River Nile at Met Ghamer city (about $70 \mathrm{~km}$ to the North of Cairo) and were transported to the Lab with some of the surrounding water and were put in aquaria with sandy substrate. Acclimatization of samples was done by adding and exchanging dechlorinated tap water for 96 hours without any food. Stock solutions $(1 \mathrm{gm} / \mathrm{l})$ of $3 \mathrm{CdSO}_{4} 8 \mathrm{H}_{2} \mathrm{O}$ was prepared and diluted to appropriate concentrations in glass jars (10 X10 X16 cm each). In each Jar, 10 individuals of the same size were placed in $700 \mathrm{ml}$ dechlorinated tap water containing known concentrations of Cadmium. The concentration of Cadmium in tap water (control solution) was measured and added to the known concentrations.

Thus the final concentrations of the experimental solutions were in addition to the control solution (0.02mg Cd / ) , 0.52, 1.02, 4.02, 8.02 and $10.02 \mathrm{mg} \mathrm{Cd} / \mathrm{l}$. Jars were supplied by aeration throughout the experiment by the same level.

The media of the Jars were renewed every day to maintain a constant level of Cadmium in both treated and control animals. The dead animals were counted and removed from the Jars every 12 hours intervals for 96 hours. The dead animals were detected when they fail to close their 
shells upon contact. The animals retained in each Jar were separately rinsed with distilled water and kept in a deep freezer until heavy metals were determined.

\section{I- Preparation of sample for the determination of $\mathbf{C d}$}

Soft tissues were removed from shells of animals of each concentration separately. They were oven dried to a constant weight at $105^{\circ} \mathrm{C}$ for 48 hours in Silica beakers. The dried materials were ground in an Agat mortar.

\section{II-Chemical analysis}

A representative sample of a definite weight of each of soft tissue and shell were separately heated in 1:1 mixture of conc. sulphuric acid and conc. nitric acid for about 5 hours at $50-60{ }^{\circ} \mathrm{C}$ until complete decomposition of organic matter. The digests were filtered and diluted to final volume of $100 \mathrm{ml}$ in a volumetric flask, using distilled water. The level of Cadmium was determined by atomic absorption spectrophotometer (Perkin-Elmer-2380).

In this study, the toxicity of Cadmium on Corbicula fluminalis was determined by LC50 after 96h. . The data were evaluated according to Behrens-Karber's method by means of the following formula (Klassen, 1991);

$$
\mathrm{LC} 50=\mathrm{LC} 100-[(\mathrm{ab}+\ldots . .+\mathrm{ab}) / \mathrm{n}]
$$

where LC50 and LC100 indicate the lethal concentrations for the $50 \%$ and $100 \%$ of the samples, " a " is the difference between two consecutive concentrations," b" the arithmetic mean for the mortality caused by the two consecutive concentrations and " $n$ " is the number of samples in each group.

\section{RESULTS}

Specimens of Corbicula fluminalis were subjected to control, 0.52, 1.02, 4.02, 8.02 and $10.02 \mathrm{mg} / \mathrm{l}$ of Cadmium solution for 96 hours. Table (1) shows the relation between the Cadmium concentration and the mortality rate of Corbicula fluminalis. The mortality rate did not exceed $10 \%$ during 96h. at Cadmium concentration of $0.02 \mathrm{mg} / \mathrm{l}$, while it was $100 \%$ at 8.02 and $10.02 \mathrm{mg} / \mathrm{l}$.

The value of $96 \mathrm{~h}$. LC50 of Cadmium on this species was found to be $0.52 \mathrm{mg} / \mathrm{l}$. This value was estimated to be $0.59 \mathrm{mg} / \mathrm{l}$ with the Behrens Karber's method indicating good agreement with the present value. 


\section{Bioaccumulation of $\mathrm{Cd}$ in soft tissue}

Corbicula fluminalis exposed to control $(0.02 \mathrm{mg} / \mathrm{l})$ for $96 \mathrm{~h}$. accumulated $119 \mathrm{mg} / \mathrm{l}$ in soft tissue. By increasing concentration of Cd in solution to $1.02 \mathrm{mg} / \mathrm{l}$, the accumulation of Cd increased to $438 \mathrm{mg} / \mathrm{kg}$ and an increasing in the concentration of $\mathrm{Cd}$ in solution to about 8 fold (from $1.02 \mathrm{mg} / \mathrm{l}$ to $8.02 \mathrm{mg} / \mathrm{l})$, the animal accumulated about 4 fold its concentration in its soft tissue (Fig. 1). The concentration factor was decreased from 5950 at the control to 209.6 at high concentration (8.02mg/l) ( Table 2).

\section{Bioaccumulation of $\mathrm{Cd}$ in shell}

The concentrations of $\mathrm{Cd}$ in the bivalve shells were reported to be lesser than the coresponding concentrations of $\mathrm{Cd}$ in soft tissues. Increasing of $\mathrm{Cd}$ concentration from 0.52 to $1.02 \mathrm{mg} / \mathrm{l}$ in solution (about 2 fold) led to the increase of Cd in shells about two fold from $37 \mathrm{mg} / \mathrm{kg}$ to $76 \mathrm{mg} / \mathrm{kg}$ (Table 3, Fig. 2). On the other hand, the concentration factor was decreased from a maximum of about 1120 at the control $(0.02 \mathrm{mg} / \mathrm{l})$ to a minimum of about 32.3 at high concentration (8.02 mg/l) (Table 3).

\section{DISCUSSION}

Bivalves are commonly available organisms that are abundant in the fresh water as well as in the marine environment .They have been suggested as ideal contamination indices in aquatic ecosystems because of their wide distribution, extensive population, sedimentary nature and the ability to accumulate contaminants (El Shenawy, 2004). Moreover, they close their shells for an extended period of time as escape behaviour or to exclude themselves from the outside environment when exposed to a contaminant (Wildridge et al., 1998).

The present bivalve genus Corbicula has high filtration rates, ease of collection, maintenance in the laboratory and being sensitive to environmental changes making it particularly usefel for biomonitoring purposes (Doherty, 1990).

Increasing use of contaminating chemicals in many industrialised parts of the world makes the development of ecotoxicity measurment techniques is an absolute necessity (Brandao et al., 1992). The first step is the acute toxicity test which can be carried out using bacteria, invertebrates and fish in order to show the potential risks of these chemicals (OECD, 1993; Yilmaz et al., 2004).

The present results accorded with Behrens -Karber method, where 96 h. LC50 value for Corbicula fluminalis exposed to different Cd 
concentrations was $0.52 \mathrm{mg} / \mathrm{l}$, while the value was estimated to be 0.59 mg/l with Behrens-Karber's method (Klassen,1991) .

The 96h. LC50 of Copper and Zinc for the same species were 0.50 and $17.5 \mathrm{mg} / \mathrm{l}$ respectively (abdel Gawad, 2001) compared to $0.52 \mathrm{mg} / \mathrm{l}$ for $\mathrm{Cd}$. This means that the toxicity of $\mathrm{Cu}>\mathrm{Cd}>\mathrm{Zn}$ and so this species is more tolerant to Zinc than to Cadmium or Copper. Unfortunately, the effect of Cd on Corbicula fluminalis was not so fare examined before to be compared, however some studies have defined LC50 of Cd for some other freshwater bivalves. They reported that $96 \mathrm{~h}$. LC50 of Cadmium for Caelatura prasidense was $0.53 \mathrm{mg} / \mathrm{l}$ (Abdel Gawad, 2005), for Caelatura teretiuscula was $5 \mathrm{mg} / \mathrm{l}($ Saad and Emam, 1998) and for Caelatura aegyptiaca was $5 \mathrm{mg} / \mathrm{l}$ after 10 days (Ibrahim et al., 1997). The differences between the values of LC50 of Cadmium for different bivalve species agree with Widerholm (1984) and Voshell et al.(1989 ) who stated that some marine organisms are very sensitive to heavy metals while others are resistant.

In this study, the bioaccumulation of Cadmium in Corbicula fluminalis was increased by increasing the concentration of Cadmium solution, while the concentration factors decreased. This agree with Wolf (1975); Kay (1985); Augier et al. (1992); Ramadan et al. (1997) and Abdel Gawad (2001\& 2005). More over it was found that concentrations of Cadmium were lower in shell than the corresponding values in soft tissue. This seems to be a common behavior for many aquatic organisms (Hare et al., 1991; Abdel Gawad, 2001 \& 2005), where the exoskeleton of contaminated organisms contains smaller amounts of trace metals relative to internal parts.

\section{REFERENCES}

Abdel Gawad, S.S. (2001). Studies on benthic invertebrates of Nile River at Helwan Region. Ph.D. Thesis, Fac. Sci., Mansoura Univ., 138pp.

Abdel Gawad, S.S. (2005). Toxicity and bioaccumulation of some heavy metales in fresh water bivalve (Caelatura prasidens Cailliaud, 1827). J. Egyp. Acad. Soc. Environ. Develop. 6(2): 137-150.

Augier, H.; Park, W.K. and Ramonda, G.R. (1992). Study of geographical seasonal metal content variations in different parts of the edible sea urchin Paracentrotus lividus, from three provincial 
test area. Revue international d,Oceanographie Medicale. 107$108: 75-87$.

Barak, N.A.E. and Mason, C.F. (1990 ). A catchment survey for heavy metals and using the eel Anguilla anguilla Chemosphere, 21 (4-5) : 695-699.

Boltovskoy, D.; Izaguirre, I. and Correa, N. (1995). Feeding selectivity of Corbicula fluminea (Bivalvia) on natural phytoplankton. Hydrobiol., 312:171-182.

Brandao, C. ; Bohets, H.L.; Vyver, I.E. and Dierickx, P.J. (1992). Correlation between the in vivo cytotoxicity to cultured fathead minnow fish cells and fish lethality data for 50 chemicals. Chemosphere, 25:553-562.

Doherty, F.G. (1990). The Asiatic clam Corbicula spp. as abiological monitor in freshwater environments. Environ. Monitor. \&Assessm. 15:143-181.

El Shenaway, N.S. (2004). Heavy metal and microbial depuration of the clam Ruditopes decussates and its effect on bivalve behaviour and physiology. Environ. Toxicol., 19:143-153 .

Hakenkamp, C.C. and Palmer, M.A. (1999). Introduced bivalves in freshwater ecosystem :the impact of Corbicula on organic matter dynamics in a sandy stream. Oecolog., 119:445-451.

Hakenkamp, C.C.; Ribblett, S.G.; Palmer, M.A.; Swan, Ch.M.; Reid, J.W. and Goodision, M.R. (2001). The impact of an introduced bivalve (Corbicula fluminea) on the benthos of a sandy stream. Freshwater Biol., 46: 491-501.

Hare, L.; Tessier, A. and Campell, P.G.C. (1991). Trace element distributions in aquatic insects: variations among genera, elements and lakes. Can. J. Fish. Aquat. Sci., 48:1481-1491.

Ibrahim, A.A.; Sleem, S.H.; Bahgat, F.G. and Ali, A.S. (1997). Effect of certain water pollutants on the biology of the fresh water clam Caelatura (unio) aegyptiaca (Bivalvia). Egypt. J. Aquat. Biol. \& Fish., 1: 47-65. 
Isom, B.G. (1986). Historical review of Asiatic bivalve (Corbicula) invasion and biofouling of waters and industries in the Americas. American Malacological Bull. Special Edition,2:16.

Kay, S.H. (1985).Cadmium in aquatic food webs. Residue, Rev., 96:1343.

Klassen, C.D. (1991). Principles of toxicology. In: Pharmacological Basis of Therapeutics. Gilman, A.G.; Tall, T.W.; Nies, A.S. and Taylor, P. (Eds), ${ }^{\text {th }}$ ed. McGraw Hill, pp.49 -61.

McMahon, R.F. (1991). Mollusca: Bivalvia In: Ecology and Classification of North American FreshWater Invertebrates (Eds.J.H.Thorp \&A.P.Covich) pp.315-390. Academic Press, San Diego.

OECD (Organization for Economic Co-operation and Development) 1993. OECD Guidelines for testeng of chemicals. OECD Paris.

Phelps, H.L. (1994). The asiatic bivalve (Corbicula fluminea): invasion and system level ecological change in potomac River estuary near washington D.C. Estuaries, 17: 614-621.

Ramadan, Sh.E. ; Khalil, A.N.; Dowidar, N.M. and El Sonbaty, S.F. (1997). Toxicity and bioaccumulation of $\mathrm{Cu}$ and $\mathrm{Zn}$ in two isopod species (Crustacea Bull. Nat. Inst. Oceanogr. \& Fish. A.R.E., 23: 135-154.

Reid, R.G.B; McMahon, R.E.; Foighil, D.O. and Finnigon, R. (1992). Anterior in halant currents and pedal-Feeding in bivalves. veliger, 35:93-104.

Saad, A.A. and Emam, W.M. (1998). Toxicity and bioaccumulation of heavy meats in the fresh water bivalve Calatura teretiuscula Egypt.J.Biol.and fish. 2 ( 4) :15-27.

Selvi, M.; Gul, A. and Yilmaz, M. (2003). Investigation of acute toxicity of Cadmium Chloride $\left(\mathrm{CdCl}_{2} \mathrm{H}_{2} \mathrm{O}\right)$ metal salt and behaviaral changes it cause on in water Frog (Rana ridibunda palls,1771). Chemosphere, 52:259-263. 
Silverman, H.; rchberger, E.E.; Lynn, J.W. and Dietz, T.H. (1995). Filtration and utilization of laboratory - cultured bacteria by Dreissena Polymorpha,Corbicula fluminea and Carunculina texasensis. Biol. Bull., 189:308-319.

Vaughn, C.C. and Hakenkamp, C.C. (2001). The function of role of burrowing bivalves in freshwater ecosystems. Freshwater Biol., 46:1431-1446.

Voshell, J.R.; Layton, JR.R.J. and Hiner, S.W. (1989). Filed techniques for determining the effects of toxic substances on benthic macroinvertebrates in rock -bottom streams.pp.134-155.In Aquatic Toxicology and Hazard Assessment .12 ASTMSTP 1027 Cowgill, U.M. and Williams, L.R. (ed) American society for testing and materials.Philadelphia,PA.

Wiederholm, T. (1984). Response of aquatic insects to environmental pollution pp.508-557. In: The ecology and Aquatic Insects .Res , V.H. and Rosenberg, D.M. (ed). Proger Publishers New York,N.Y.

Wolf, P.D. (1975). Mercury content of mussels from west European coast .Mar. Pollut. Bull. , 6:61-23.

Wildridge, P.L.; Werner, R.G.; Doherty, F.G. and Neuhauser, E.F. (1998). Acute effects of potassium on filtration rates of adult zebra mussels Dreissena polymorpha .J.Great Lakes Res., 24: 629-636.

Yilmaz, M.; Gul, A. and Karakose, E. (2004). Investigation of acute toxicity and the effect of Cadmium Chloride ( $\left.\mathrm{CdCl}_{2} . \mathrm{H}_{2} \mathrm{O}\right)$ ) metal salt on behavior of guppy (Paecilia reticulata) Chemosphere, 56: 375-380. 
Table (1): 96-hour acute toxicity results of Cadmium Sulphate on Corbicula fluminalis

\begin{tabular}{|c|c|c|c|}
\hline $\begin{array}{c}\text { Concentration of Cd } \\
(\mathrm{mg} / \mathrm{l})\end{array}$ & $\begin{array}{c}\text { Number of } \\
\text { Corbicula exposed }\end{array}$ & $\begin{array}{c}\text { Number of } \\
\text { Corbicula } \\
\text { dead }\end{array}$ & $\begin{array}{c}\text { Mortality } \\
\text { rate \% }\end{array}$ \\
\hline Control (0.02) & 10 & 1 & 10 \\
\hline 0.52 & 10 & 5 & 50 \\
\hline 1.02 & 10 & 6 & 60 \\
\hline 4.02 & 10 & 6 & 100 \\
\hline 8.02 & 10 & 10 & 100 \\
\hline 10.02 & 10 & 10 & \\
\hline
\end{tabular}

Table (2): Bioaccumulation of $\mathrm{Cd}$ in soft tissue of Corbicula fluminalis after 96 h.exposure to different concentrations of Cd solution.

\begin{tabular}{|c|c|c|}
\hline $\begin{array}{c}\text { Concentration of Cd in } \\
\text { solution(mg/l) }\end{array}$ & $\begin{array}{c}\text { Concentration of Cd in soft } \\
\text { tissue }(\mathrm{mg} / \mathrm{kg})\end{array}$ & C.F(Concentration factor) \\
\hline 0.02 (control) & 119 & 5950 \\
\hline 0.52 & 308 & 592.3 \\
\hline 1.02 & 438 & 429.4 \\
\hline 8.02 & 1681 & 209.6 \\
\hline
\end{tabular}

Table (3): Bioaccumulation of Cd in shell Corbicula fluminalis after $96 \mathrm{~h}$. exposure to different concentrations of Cd solution.

\begin{tabular}{|c|c|c|}
\hline $\begin{array}{c}\text { Concentration of Cd in } \\
\text { solution (mg/l) }\end{array}$ & $\begin{array}{c}\text { Concentration of Cd in } \\
\text { shell }(\mathrm{mg} / \mathrm{kg})\end{array}$ & C.F(Concentration factor) \\
\hline $0.02($ control) & 22.4 & 1120 \\
\hline 0.52 & 37.0 & 71.15 \\
\hline $1.02 \mathrm{l}$ & 76.0 & 74.5 \\
\hline 8.02 & 258.8 & 32.27 \\
\hline
\end{tabular}




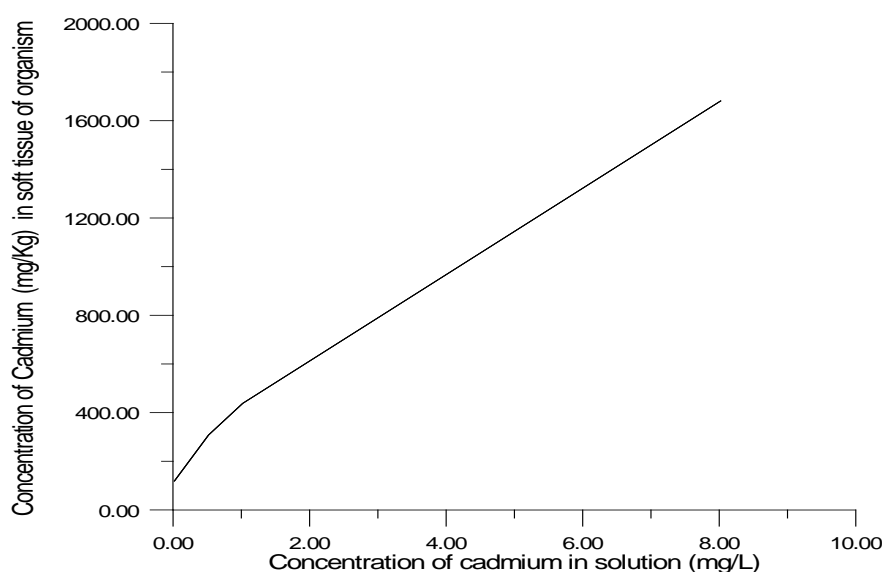

Fig. [1]: Bioaccumulation of Cd in soft tissue of Corbicula fluminalis after $96 \mathrm{~h}$. exposure in different concentrations of $\mathrm{Cd}$ solution

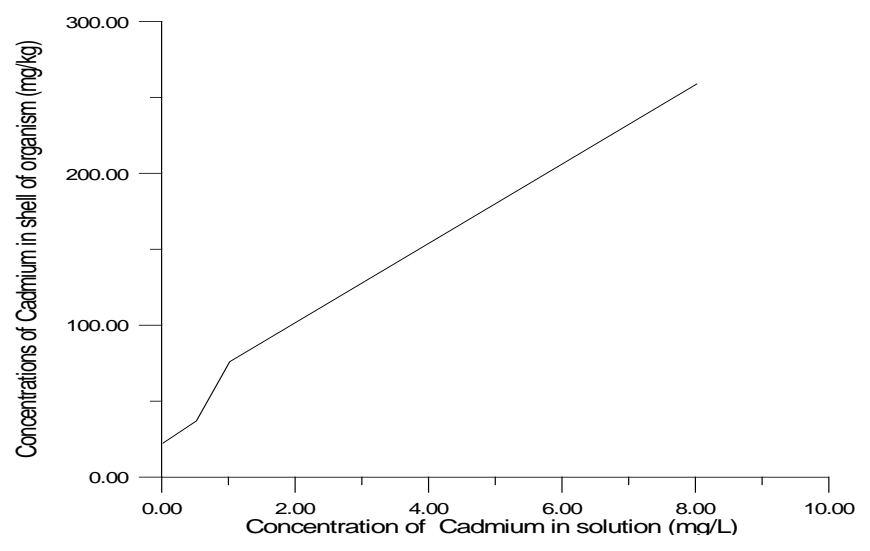

Fig. [2]: Bioaccumulation of Cd in shell of Corbicula fluminalis after $96 \mathrm{~h}$. exposure in different concentrations of Cd solution. 